\title{
PASTORAL COLETIVA DO EPISCOPADO BRASILEIRO - 1915: HÁ CEM ANOS A CONSTRUÇÃO DE UMA IGREJA1
}

\author{
The Brazilian Episcopate Collective Pastoral - 1915: the construction of a church 100 \\ years ago
}

Euclides Marchi

Universidade Federal do Paraná

Professor Aposentado do Departamento de História

E-mail: euclides.marchi@yahoo.com.br

\begin{abstract}
RESUMO: Em 17 de janeiro de 1915, o episcopado das Províncias Eclesiásticas Meridionais comunicava ao clero e fieis "o resultado das Conferências Episcopaes realisadas na cidade de Nova Friburgo de 12 a 17 de Janeiro de 1915". O documento completo continha, além das atividades das próprias conferências, a Pastoral Coletiva e as Constituições Diocesanas das Províncias Eclesiásticas Meridionais do Brasil. A análise desta documentação aponta para o esforço na direção da construção da Igreja Católica Romana no Brasil, após a separação do Estado. Observa-se ainda que as Constituições Diocesanas representam, especialmente, o desencadear de uma caminhada livre e autônoma. Também constata-se que o discurso episcopal aposto nestes documentos revela que as autoridades eclesiásticas, após várias conferências, consolidavam suas opções em prol da europeização e da reformulação dos costumes do clero, dos fieis, dos rituais e das práticas do catolicismo. Estas práticas, agora normatizadas nas Constituições, deveriam ser adotadas por todas as unidades da Igreja; isto é, dioceses, paróquias, seminários, ordens, congregações religiosas e associações leigas. Além disso, os bispos reafirmavam que eles se constituíam na autoridade máxima em suas dioceses e a eles todos deveriam obediência, inclusive as ordens e congregações religiosas. Finalmente, ao se analisar esta documentação, conclui-se que a aliança entre a Igreja Católica Romana e o Estado brasileiro além de perversa, ambos somaram prejuízos e, por longo tempo sofreram para suprimir a herança que dela restou, se é que já foi totalmente suprimida.
\end{abstract}

Palavras chave: Igreja Católica Romana, episcopado, análise do discurso, catolicismo no Brasil.

ABSTRACT: On the seventeenth of January 1915, the episcopate of Ecclesiastical Provinces of the South reported the Episcopal Conferences results to the clergy members and the faithful ones. Being held in Nova Friburgo, the conferences were initiated on the twelfth and were concluded on the seventeenth of January 1915. Aside from the conferences particular activities, the complete document contained the Collective Pastoral and the Diocesan Constitutions of the Ecclesiastical Provinces of the South. The analysis of this documentation reveals the effort to construct the Roman Catholic Church in Brazil, after its detachment from the state. The Diocesan Constitutions clearly represent the beginning of a more autonomous and free course. The episcopal speech seen in these documents also declares that, after several conferences, ecclesiastical authorities established their support on the europeanization and the reformulation of the customs of the clergy, the faithful ones, the rituals and the catholic practices. Regulated in the Constitutions at present, these practices should be adopted by all church units, i.e. dioceses, parishes, seminaries, orders, religious congregations and lay associations. Furthermore, bishops reaffirmed supreme authority in their own dioceses, whose regulations every individual should obey, no exception to the orders and religious congregations. Finally, by analysing this documentation, it is possible to conclude that the alliance between the Roman Catholic Church and the Brazilian State was, other than perverse, counterproductive to both. Causing damages for an extended period of time, the church and the state suffered to eliminate the remnants of the difficult situation. In fact, if they were able to completely suppress the past is still debatable.

Keywords: Roman Catholic Church, episcopate, discourse analysis, Brazilian Catholicism.

${ }^{1} \mathrm{O}$ uso do termo Igreja significa Igreja Católica Romana. 


\section{Introdução}

Há cem anos, um documento assinado por um Cardeal, seis Arcebispos e vinte Bispos comunicava ao clero e aos fieis "o resultado das Conferências Episcopaes realisadas na cidade de Nova Friburgo, de 12 a 17 de Janeiro de 1915". O texto final das Conferências continha as Atas, a Alocução de abertura, a Pastoral Coletiva e, o mais importante, as “Constituições Diocesanas das Províncias Eclesiásticas Meridionais do Brasil" complementadas por oitenta e quatro Apêndices. O episcopado informava que elas eram o resultado e a síntese das conferências de 1901, 1904, 1907, 1911, revistas, emendadas e consolidadas no documento publicado em 1915 e substituíam, em definitivo, as Constituições Primeiras do Arcebispado da Bahia ordenadas por Dom Sebastião Monteiro da Vide em 1707. Cardeal, arcebispos e bispos eram os titulares das dioceses das Províncias Eclesiásticas de São Sebastião do Rio de Janeiro, Mariana, São Paulo, Cuyabá e Porto Alegre as quais compunham a Província Meridional do Brasil.

A partir da primeira década do século XX as "Conferências Episcopais" respondiam aos apelos do Concílio Plenário Latino Americano de 1899, realizado em Roma por convocação do papa Leão XIII, no qual se recomendava ao episcopado a realização de encontros periódicos de três em três anos. Um dos objetivos primordiais daquele Concílio fora o de unificar o discurso, rever e reformar os costumes do clero e dos católicos, organizar os ritos e as práticas litúrgicas e implantar as diretrizes da europeização/romanização da Igreja Católica em toda a América Latina. As decisões foram publicadas num documento denominado Acta et Decreta Concilii Plenarii Americae Latinae. Das conferências Episcopais brasileiras resultaram Cartas Pastorais Coletivas, as quais se tornaram um instrumento fundamental para atingir o objetivo proposto pelo Concílio e para organizar os procedimentos que deveriam ser adotados pela Instituição no Brasil. Aliás, as Cartas Pastorais, fossem elas coletivas ou individuais, serviam como instrumento de comunicação entre a hierarquia e os leigos e não representavam uma novidade, pois o hábito de escrever cartas aos fieis fora um procedimento adotado desde o tempo dos apóstolos.

No horizonte deste cenário, esta pesquisa tem como objetivo destacar a importância da Carta Pastoral Coletiva de 1915 e das Constituições Diocesanas para se entender a construção discursiva e as orientações dadas a toda a catolicidade no 
processo de ordenamento institucional que seria implantado no Brasil a partir daquela data.

\section{Unidade discursiva e regulamentação das práticas}

O objetivo de unificar o discurso e de se evitar as fragmentações organizacionais, doutrinárias e teológicas proposto pelo Concílio Plenário Latino Americano, repercutiu de forma direta nas Pastorais Coletivas dos bispos do Brasil. Em nenhuma delas, todavia, essa repercussão foi mais explícita do que na Pastoral Coletiva de 1915 e nas Constituições Diocesanas. Muitos dos seus 1677 itens eram a reprodução das Atas e dos Decretos daquele Concílio.

A leitura desse conjunto de documentos aponta para dois objetivos: o primeiro era abrir caminhos para construir a Igreja Católica Romana ${ }^{2}$ no Brasil, recuperando as perdas impostas pelo governo imperial e o segundo era consolidar liderança dos bispos e conquistar novos espaços na sociedade brasileira. No entanto, um estudo mais acurado remete também e necessariamente, para a análise do discurso por eles produzido, pois, ao reproduzir o percurso definido pelo Concílio Plenário de 1899, assumiam o papel de sujeitos de uma discursividade que impunha um comportamento religioso que deveria ser implantado em todas as dioceses do Brasil. Há que se observar, ainda, que o texto da Pastoral Coletiva que resultara das Conferências de 1915 continha uma retórica própria dos discursos institucionais, quer dizer, era portador das características da fala oficial, típica dos porta-vozes autorizados, para os quais os limites de sua autoridade coincidiam com os da delegação recebida da instituição. As características específicas da linguagem, fosse ela do papa, dos bispos ou daqueles que ocupavam posições de autoridade numa determinada instituição, refletiam o poder que lhe fora delegado. Desta forma, o papa assumia a função de porta-voz da Igreja, ou de Vigário de Cristo e, portanto, um porta-voz autorizado e sua fala concentrava o capital simbólico consagrado pelo grupo que o instituíra e lhe conferira esse poder e que, ao mesmo tempo, aceitava que ele se apresentasse como o procurador da instituição ou do próprio grupo.

Certamente seria uma imprudência reduzir ou delimitar o conteúdo das Conferências de 1915 à simples condição de linguagem ou apenas à análise do discurso.

\footnotetext{
${ }^{2}$ Construir a Igreja Católica Romana no Brasil, entende-se, neste texto, substituir a Igreja Regalista que prevaleceu no Império, durante a vigência do Padroado. Isto é, construir uma Igreja organizada em consonância com as orientações de Roma.
} 
Todavia, Helena Brandão, ao citar BRAGA (M.L.S.) destaca que a linguagem “(...) é o 'medium' social em que se articulam e defrontam agentes coletivos e se consubstanciam relações interindividuais" (BRANDÃO, 1998:12). Por isso, cabe ressaltar que o discurso constitui-se num espaço em que saber e poder se articulam, pois quem fala, fala de algum lugar, a partir de um direito reconhecido institucionalmente. Esse discurso, que passa a ser verdadeiro e que veicula saber (o saber institucional) é também gerador de poder. E, por ser gerador de poder, naquela circunstância era preciso unificá-lo, controlá-lo e redistribuí-lo de forma organizada e eficaz.

Munidos destas concepções a respeito do discurso, é possível voltar aos documentos produzidos pelo episcopado no início do XX, para afirmar que eles eram portadores de uma linguagem específica e de um discurso próprio que revelava as preocupações com o statu quo da Instituição que governavam; ou seja, tanto Nela, quanto nas dioceses propriamente ditas, prevalecia uma desorganização endêmica, provocada pela gestão que fora implantada no decorrer do período colonial e que perdurara também durante o Império. Com a extinção do padroado e a consequente separação entre o Estado e a Igreja Católica, deu a esta a liberdade de se organizar e definir seus próprios rumos. Embora não caiba neste texto uma discussão mais detalhada deste período, há que se ressaltar que da leitura do documento produzido pelas Conferências Episcopais de 1915 deduz-se que o episcopado passara a considerarse imbuído de um poder e de uma liderança que exigia deles atitudes diferentes daquelas que prevaleceram até o fim do governo imperial. Os tempos eram outros e a linguagem deveria ser adequada às necessidades do momento e ao perfil dos enunciadores que, de forma afirmativa, comunicavam ao clero e aos fieis o resultado de seu trabalho e assumiam uma postura de enunciadores instituídos e elevados à categoria de bispos e, portanto, detentores de poderes para legislar segundo os parâmetros previamente estabelecidos pela Igreja Católica Romana. Por força dessa instituição, os bispos se consideravam sucessores dos apóstolos e representantes autorizados de uma Igreja que, segundo eles, fora criada por Jesus Cristo e que, portanto, tinha um caráter divino, e a eles fora concedida autonomia em relação ao poder político e aos governantes do Estado Republicano.

Desta forma, se o cenário e a conjuntura descritos pelos próprios bispos mostravam que Igreja, no momento da publicação da Pastoral e das Constituições 
Diocesanas, vivia uma situação preocupante, era preciso adotar um discurso cujo caráter ordenatório pudesse transformar o comportamento de toda a catolicidade brasileira. A situação era angustiante, pois além de minguado, o clero era mal formado, sem comprometimento com as causas do catolicismo, com seus rituais e com sua liturgia e os "numerosos católicos oficiais" eram mais afeitos aos rituais e aos cultos vivenciados à margem dos templos. Naquele momento, descortinava-se para o episcopado brasileiro a necessidade de retomar as diretrizes traçadas pelo Concílio de Trento, reiteradas pelos Papas e reafirmadas pelo Concílio Plenário Latino Americano. E se a tarefa era penosa, também era estimulante. Era o momento oportuno para iniciar a construção de uma nova Instituição. E porque eram bispos de uma Igreja que marcara sua presença deste a chegada dos portugueses ao Brasil não se intimidavam frente ao momento de crise e de dificuldade pelos quais passavam a sociedade e os católicos. Sabiam que não falavam em seu próprio nome, mas em nome de uma Instituição à qual lhe atribuíam um caráter divino e, portanto, falavam em nome Daquele que a criara. Em função disso, o seu discurso assumia uma característica de força e vinha imbuído de um espírito de apostolado e de uma missão recebida do alto. E, se por parte deles havia uma disposição de construir a Igreja Católica Romana do Brasil, certamente esperavam do clero e dos católicos a mesma disposição para executar essa tarefa. Para isso, o discurso deveria ser didático e portador de autoridade e de mando.

Portanto, sabiam e acreditavam que dentro da estrutura organizacional e administrativa, eles (os bispos), como enunciadores, estavam credenciados a mandatários e com poder de subscrever os documentos, pois todos haviam passado pelo ritual de sagração. Ritual esse que, além de conferir eficácia simbólica à sua autoridade, garantia fidedignidade à sua nomeação e ao poder legal que lhes fora conferido em ato público e solene. Eles eram as vozes instituídas que faziam uso de uma linguagem autorizada, portadora das condições sociais e legais de uso do discurso e da ação. Complementando com o que ensina Pierre Bourdieu "o poder das palavras é apenas o poder delegado do porta-voz cujas palavras (...) constituem no máximo um testemunho, um testemunho entre outros da garantia da delegação de que está investido" (BOURDIEU, 1996: p. 87). Assim, além das palavras, simbolicamente os bispos sentiam-se pastores (portando o báculo do governo das almas e a mitra do poder diocesano) e mestres (fundamentavam suas ideias no Evangelho e nas decisões da 
Igreja) e reconheciam que neles se concentrava o poder legislativo, o judiciário e o coercitivo. Poder de definir leis, de julgar, de proibir, de permitir, de condenar e de absolver. Por isso era fundamental deixar claro que na condição de bispos haviam sido investidos da mais alta autoridade nas suas dioceses, incumbidos de reger as coisas sagradas sob orientação do Papa e da Sé Romana. Tinham a autoritas, dentro das fronteiras de sua diocesis. Posicionavam-se como portadores de um vasto e amplo poder que deveriam exercê-lo como pastores e presidir a seus fieis como irmãos. Cada bispo, representante e responsável maior pelos assuntos da religião em sua diocese deveria deter o monopólio das explicações e do sentido dos bens sagrados.

Os sacramentos, a fé, o culto, a liturgia e a formação do clero recebiam interpretação e análise institucional, exarada pelos que foram consagrados e instituídos para fazê-lo. Era nessa condição que o episcopado brasileiro lançava mão desse poder e dessas representações para modificar as práticas dos leigos, inculcando-lhe outras, melhor ajustadas aos interesses do momento. E como autoridades legítimas e aceitas ordenavam que as decisões tomadas pelas conferências do episcopado, expressas na pastoral e nas constituições fossem lidas nas paróquias e nos seminários, para que ninguém alegasse ignorância. Assim, pensando na Instituição como um todo, davam início a um amplo processo de substituição das manifestações livres e espontâneas do culto, do misticismo e do profetismo por discursos e ritos burocratizados, nem sempre afeitos à religiosidade dos seus diocesanos.

\section{A Construção da Igreja Católica Romana no Brasil}

Convicto de que era preciso mudar a forma de atuação, o episcopado, ao avaliar a situação da Igreja Católica Romana no Brasil na segunda metade do século XIX e nas primeiras décadas do XX, convenceu-se de que os quatro séculos de aliança com o Estado haviam sido prejudiciais a Ela, porque os governantes pouco primaram pela dedicação ao catolicismo e às suas crenças. Uma legislação regalista, uma política intervencionista e de esvaziamento das ordens religiosas, um descrédito generalizado em relação aos padres e o esfacelamento das práticas do catolicismo definiram os espaços de atuação das duas instituições. Era preciso, sem a interferência dos governantes, construir a Instituição, organizar a hierarquia, formar um novo clero e implantar novos cultos e devoções, moralizar os costumes, incentivar a vivência 
litúrgica e abandonar os princípios constitucionais regalistas.

Os conflitos entre as autoridades eclesiásticas e as governamentais, bem como os limites interpostos pela legislação agravaram a convivência e o respeito entre as instituições deixando claro que a hierarquia católica já não se conformava com uma Igreja transformada em repartição pública. Caracterizava-se uma disputa onde o que estava em jogo era o poder. E a pergunta era: a quem se deveria obedecer? Ao Papa, ou ao governo brasileiro? A definição do impasse representava a continuidade do preceito firmado na Constituição Imperial ou então, a separação entre a Igreja e o Estado. Não eram apenas os bispos que se ressentiam da perversidade dessa aliança. Os governantes também começaram a considerar a necessidade de se implantar um Estado liberal, leigo, secularizado e um governo sem religião. Embora essa opção abalasse as centenárias relações, a decisão culminou com um processo sumário e unilateral de separação adotado pelo Governo Republicano, pondo fim ao sistema de padroado e ao Estado confessional e regalista. A Igreja Católica Romana era, legal e juridicamente, equiparada às demais confissões religiosas, livre para atuar na sociedade brasileira e o catolicismo deixava de ser a religião oficial do Estado. Estava decretada a alforria: ambos reelaboravam discursos e partiam para uma ação autônoma. Enquanto o Estado construía a República, Ela consolidava as relações com o Vaticano e tornava-se uma Instituição irremediavelmente atrelada a Roma e europeizada. Uma trajetória sem opções, um discurso com parâmetros preestabelecidos e uma mudança previamente delineada.

Esse conjunto de opções vinha respaldado pela constatação de que ao findar o século XIX, eram flagrantes os sinais da decadência institucional. A conjuntura mantivera-se ao longo dos anos: padres pouco afeitos ao exercício do ministério sacerdotal, seminários funcionando precariamente, ordens religiosas minguando por falta de candidatos, perda do patrimônio e a pregação do Evangelho completamente esquecida. Somava-se a isso um explícito desprezo governamental para com as questões da religião, dificultando a criação de dioceses, deixando vagos os cargos de vigário colado nas paróquias e os de professor para as cadeiras dos cursos de formação do clero e criando obstáculos à consolidação do poder pontifício. Estava posta para Ela a dificuldade de formar um corpo de especialistas adequadamente preparados para as exigências de uma catolicidade europeizada. Cabe lembrar que o sistema de padroado 
mantido pela constituição imperial, sobrepunha o Estado ao aparelho eclesiástico e transformava os brasileiros em súditos e cidadãos católicos. Essa ambiguidade afetara o comportamento dos católicos, constituíra um clero vacilante entre manter seu status de funcionário público e, ao mesmo tempo, de sacerdote de uma Igreja sem personalidade. Um clero que, ao manifestar-se sobre temas não litúrgicos, ou que se referissem às questões institucionais, não raro criava constrangimentos junto a Ministros e outras autoridades, com o envolvimento em querelas que exigiam a intervenção do próprio Imperador.

Por esta razão, a separação entre a Igreja Católica Romana e o Estado liberava o episcopado para iniciar a construção institucional, fixar diretrizes e normatizar as atividades pertinentes aos serviços da religião e, especialmente, para adotar as medidas necessárias à implantação das orientações advindas de Roma. Intensificava-se o ordenamento interno, romanizavam-se os procedimentos pastorais, litúrgicos e devocionais e publicava-se um conjunto de normas e resoluções que iriam orientar o povo católico na prática da religiosidade e de sua inserção institucional. O primeiro quarto de século pós-separação, longe de se caracterizar como um período de desânimo ou de "trevas" foi de grande vitalidade, no qual a estrutura organizacional cresceu e se expandiu e produziu-se um discurso doutrinário que marcou um dos mais ricos processos de construção e confirmação institucional. Implantou-se um trabalho que revelou a capacidade da Igreja organizar-se interna corporis e de produzir novos quadros de clérigos e de leigos convictos defensores não apenas da europeização da Instituição, mas também engajados nas causas da catolicidade. Os seminários foram modernizados e outros foram fundados, implantou-se uma rede de escolas católicas e institutos de assistência, celebraram-se novas alianças e organizou-se uma funcional e ativa burocracia, com estruturas adequadas para consolidar seu poder no interior da sociedade brasileira.

Para garantir os caminhos da espiritualidade e o sucesso das medidas adotadas, criaram-se novas dioceses e paróquias, clericalizou-se e implantaram-se outros cultos, incentivou-se a presença dos católicos nas cerimônias religiosas e reforçou-se a vigilância sobre o celibato sacerdotal. Aos ataques dos adversários reagiu-se com um conjunto de iniciativas que significaram, sobretudo, o fortalecimento institucional e a garantia das condições de sobrevivência em meio à concorrência ideológica e cultural 
do mundo moderno. $\mathrm{O}$ aumento do número de dioceses e de bispos, embora não suficiente para as demandas do tamanho do Brasil, contribuiu para que a Instituição adquirisse uma nova face, organizasse suas estruturas de funcionamento e unificasse as práticas da religiosidade.

Alguns dados numéricos contribuem para clarear esse dinamismo que envolveu as autoridades eclesiásticas nas décadas que marcaram o início da caminhada como Instituição autônoma e livre das pressões do Estado Imperial. Sabe-se que o primeiro bispado do Brasil foi criado na Bahia em 1551, sendo indicado como seu titular o bispo Dom Pedro Fernandes Sardinha. A implantação dos demais fora muito lenta, revelando que o poder público resistia ao aumento do número de dioceses. Diferente era o caso das paróquias pois, além de sua função religiosa, também eram unidades administrativas e políticas, e que, por isso, se expandiram com muito mais rapidez, embora muitas ficassem sem vigários colados. Assim, após quatro séculos de catolicismo como religião oficial, a situação era a seguinte: 1890 a Igreja Católica Romana do Brasil estava dividida em 12 dioceses. Em 1892, o número aumentara para 16 e em 1900 já contava com 02 arquidioceses e 15 dioceses. Esse crescimento fica ainda mais evidente quando se observa que em 1910 contabilizavam-se 08 arquidioceses e 29 dioceses, e que, em 1915, mantidas as 08 arquidioceses, o número de dioceses passara para 38.

Três datas podem dar uma visão mais concreta do aumento do número de dioceses: em 1822 - ano da Independência havia 01 arcebispado e 06 bispados; em 1889 - ano da República, havia 01 arcebispado e 11 bispados e em 1922 - ano do Centenário da Independência, eram 13 arcebispados e 39 bispados. Assim, se nesta conjuntura as pastorais individuais ou coletivas se tornaram um dos principais instrumentos de construção das novas ou de reconstrução das dioceses já existentes, não será exagero afirmar-se que, também nesta conjuntura, a Pastoral Coletiva de 1915, desempenhou um papel fundamental e incomparável na construção de toda a Igreja Católica Romana no Brasil.

\section{A Pastoral Coletiva e as Constituições Diocesanas de 1915: a organização interna e a revitalização do catolicismo}

A Pastoral Collectiva e as Constituições Diocesanas das Províncias Ecclesiasticas Meridionaes do Brasil publicadas em 1915 representam o trabalho do episcopado brasileiro nas cinco conferências realizadas no decorrer dos primeiros 
quinze anos do século XX. Nesta nova dinâmica institucional este Documento merece um conjunto de considerações seja do ponto de vista discursivo, seja do administrativopastoral. Os textos da Alocução de abertura das Conferências e da Pastoral Coletiva chamam a atenção, em especial, pela a análise de conjuntura feita pelos bispos. Uma análise que avalia não apenas as condições específicas da Igreja Católica Romana, mas que abrange também a situação do "Mundo civil". No olhar do episcopado, grandes foram os avanços conseguidos pelas quatro conferências anteriores no que se refere à unidade de ação, à formação do clero, à atuação dos párocos, à prática do culto, à devoção dos fieis e ao impulso dado aos movimentos sociais católicos. Também davam ênfase à deflagração da $1^{\mathrm{a}}$ Guerra Mundial, definida como a mais sangrenta e a mais monstruosa das guerras. A análise foi complementada pelas considerações sobre a morte de Pio X, realçando as suas virtudes, a sua bondade, a sua doçura e a sua tranquilidade de santo. Além disso, fora caracterizado como um papa que teve a preocupação de "manter intacto o depósito da fé e da moral cristãs", num agitado período para o pensamento humano, numa época de confusão e anarquia intelectual e fértil de inovações e "modernices descabidas". O desenho deste cenário consolidava não somente a tese da constante reafirmação da Igreja Católica como um organismo divino, como também reforçava a imagem do papa como a "alma da Igreja".

Para além da análise de conjuntura, alguns temas de ordem interna corporis eram reafirmados com intensidade: imunidade e autoridade da Igreja em tudo o que dissesse respeito à religião; incremento do clero nacional e máxima prudência nas relações com o poder civil; zelo para a preservação de sua autoridade em todas as esferas de ação - seja na religiosa e na eclesiástica, seja na civil. Qualquer movimento social ou religioso - não deveria se sobrepor às prerrogativas da Instituição. No limite, o episcopado definia a ação dos leigos como uma forma de cooperação e não de substituição daquela própria e específica da Igreja (entenda-se hierarquia e clero). Definia claramente o trabalho das congregações religiosas e valorizava sua colaboração; mas deixava claro que, apesar da autonomia quanto à forma de organização, nas dioceses elas estariam sujeitas à autoridade dos bispos. Como alternativa recomendavam que houvesse muito empenho e incremento na formação do clero nacional, pois dele dependeria o futuro da Instituição no Brasil, a regeneração do povo e da sociedade. Era um típico reforço à autoridade institucional. 
E, se a partir da primeira década do século $\mathrm{XX}$, as diversas Conferências episcopais serviram, sobretudo, para a elaboração das Constituições Diocesanas, também construíram o que pode ser considerado como "discurso fundador" da europeização da Igreja Católica Romana do Brasil. Por isso, vale a pena repetir que a política de criação de novas dioceses, com a consequente nomeação de seus bispos, resultou num conjunto de Cartas Pastorais que se constituíram e se constituem em importante documentação para que se possa entender, não somente os aspectos da religiosidade do Brasil, mas analisar as condições sociais, educacionais, culturais, políticas e econômicas de toda a sociedade. Ao descrever a realidade de sua diocese, cada bispo contribuiu para que se conhecessem as condições de vida do povo e do Brasil. Portanto, as Cartas, apesar do seu conteúdo doutrinário e pastoral e de tratarem de temas como os sacramentos - matrimônio, eucarística, confissão etc -, também traziam informações sobre os rituais, as festas religiosas, as devoções, as associações pias, a moral e os costumes, as normas e orientações disciplinares, as decisões e as determinações sobre o comportamento da sociedade no seu do dia a dia, sobre convivência nos espaços de sociabilidade laica e dos usos e costumes a serem mantidos e outros a serem implantados.

Mais especificamente, a Pastoral Coletiva de 1915 apontava, ainda, a despreocupação do povo brasileiro com o combate aos vícios e aos males e revelava a propensão para as superstições, as uniões ilícitas e para as associações inimigas de Deus e da Igreja. Enfim, dava ênfase a uma ignorância religiosa generalizada. Lamentava, acima de tudo, a falta de zelo e de empenho de alguns sacerdotes para impedir o avanço do espiritismo e do protestantismo causadores, segundo os bispos, de sérios estragos nas almas e nos corpos da população.

E, se ficara explícito o aspecto pedagógico, o discurso nela contido assumia também um viés social. Opunha-se aos assaltos à propriedade privada, aos cofres públicos, aos crimes contra a justiça, aos roubos, às demissões de empregados, aos baixos salários e às injustiças sociais. O povo católico era conclamado a se opor aos erros e à impiedade do mundo moderno e a lutar pelo ensino religioso nas escolas públicas.

No entanto, é preciso insistir no tom litúrgico-pastoral. Indicava que, em 1915, a amargura da separação estava superada e a Igreja estava refeita do abalo e em condições 
de definir sua nova trajetória. E, se as questões ligadas ao Estado haviam sido resolvidas, a grande preocupação estava em garantir o controle sobre a religião e a religiosidade do povo. Por esta razão, enquanto, por um lado, combatia abertamente o espiritismo e o protestantismo, por outro, incentivava o povo católico a se organizar em associações de meninos, de moços, de donzelas, associações pias, de caridade, de zelo para com os pobres e enfermos. Ao clero recomendava submissão e obediência aos bispos e respeito às prescrições pontifícias.

Instigante é o discurso episcopal no final da carta quando reitera:

Ensinemos ao povo a observar as leis, a respeitar as autoridades legítimas, a amar o trabalho, a acatar os direitos alheios; cimentemos e promovamos a união e concórdia, o amor entre os indivíduos e entre as classes sociais. Ensinemos que devemos concorrer para o bem da pátria com nosso voto livre e conscientemente prestado a cidadãos, que por sua honestidade privada, por sua probidade civil e econômica, por seu patriotismo e por sua fé destemida e franca o mereçam, com exclusão dos ímpios, dos imorais e dos sem caráter (IGREJA CATÓLICA. Bispos. Pastoral Coletiva, 1915).

Finalmente, percebe-se que embora nas relações com o poder civil fosse preciso usar da máxima prudência, a República estava aceita, a laicização já não incomodava tanto e as adaptações já haviam ocorrido. A Igreja, organizada institucionalmente, aceitava aproximar-se do Estado e a colaborar com os governantes. Era um novo discurso; suave, voltado para seus fiéis, para a espiritualidade, para as obras pias, para o respeito às leis, para a defesa da pátria e da religião católica.

E, se no momento da separação o episcopado teve que iniciar um aprendizado da liberdade, também se revelou capaz de controlar as dissensões internas e manter a coesão em níveis que lhe permitissem superar as cisões e construir a Instituição, preparando um corpo clerical e leigo capaz de enfrentar os embates com as diversas correntes de pensamento não católicas ou, mais especificamente, anticlericais e garantir uma presença majoritária na oferta de bens sagrados. Embora o esforço para a clericalização e a europeização das práticas litúrgicas possa representar a perda da domesticidade e docilidade do catolicismo popular, ele contribuiu para que ela mantivesse o controle sobre a religiosidade, sobre os cultos e, sobretudo, sobre a fé católica. Nesta conjuntura, cabe ressaltar que tanto a Pastoral, quanto as Constituições 
Diocesanas representaram a síntese das preocupações do episcopado no momento em que o catolicismo e a Igreja Católica Romana consolidavam sua autonomia em relação ao Estado. Há mais de cinco décadas, a hierarquia dava sinais de que faltava ao catolicismo brasileiro uma compreensão adequada da sua doutrina e da sua teologia, o que gerava uma fragilidade na definição do que seria o espaço do religioso e da organização da sociedade. Para consolidar a tese de que Ela era a instituição credora da crença e da cidadania dos brasileiros, percebeu que era fundamental organizar e implantar novos mecanismos de formação do clero e de "catolicização" dos fieis.

Esta opção ficou manifesta do texto das Constituições Diocesanas. Divididas em seis títulos: I. Fé, II. Sacramentos, III. Culto, IV. Disciplina do clero, V. Costumes do povo, VI. Promulgação das Constituições. Aos seis títulos acrescentavam-se oitenta e quatro apêndices. Além disso, cada título fora dividido em capítulos abordando conteúdos a ele relacionados.

Cabe observar que embora não se constituíssem num tratado de teologia eram um código de leis, contendo os estatutos e as resoluções para a orientação de toda a catolicidade brasileira. Os assuntos nelas elencados eram da mais alta relevância começando com o primeiro deles - a fé. Neste tópico, o clero e os católicos encontravam as orientações necessárias para o seu magistério. O título I fora dividido e oito capítulos, com um total de 141 itens. Neles os bispos detalharam não apenas a profissão da fé, mas explicitaram a pregação sobre a fé, a sua propagação, a doutrina cristã e o seu ensino, os perigos que ela corria, os principais erros modernos e os meios para evitá-los bem como o papel das escolas católicas na sua pregação e conservação.

Ao tema da fé, sucedia o título II- dos sacramentos, no qual, talvez, residisse uma das principais preocupações do episcopado na construção da Igreja: a sacramentalização da religiosidade. A administração dos sacramentos como o Batismo, a Confirmação, a Eucaristia, a Penitência, a Extrema Unção, a Ordem e o Matrimônio foram tratados em dez capítulos e trezentos e setenta e oito itens. Sem dúvida, um detalhamento completo. O próprio documento destaca no item 142: "É missão principal dos parochos procurar a santificação das almas pela exacta e escrupulosa administração dos sacramentos". Os bispos trataram desse tema com muito zelo, detalhando cada um dos sacramentos e como deveriam ser ministrados, a quem e por quem. Neste título aparece explícita a preocupação com a organização sacramental em substituição às 
práticas e aos rituais laicos. Impressiona o detalhamento doutrinal e ritualístico para cada um deles, ordenando aos párocos o cumprimento de cada recomendação contida nas Constituições.

Outra grande preocupação refere-se ao Culto. É um título composto de dezoito capítulos e quatrocentos e quarenta e oito itens, nos quais são abordados desde o culto divino, até a música sacra, perpassando pela missa, a devoção ao sagrado coração de Jesus, à virgem Maria, à Sagrada Família, a São José, aos anjos e aos santos, às relíquias, às imagens, os jejuns e a abstinência, os oratórios, as procissões e as peregrinações, as festas e as exéquias para lembrar apenas alguns. Um tema muito caro ao processo de europeização, pois nele residia um dos pontos marcantes da clericalização da prática da religiosidade. A falta de padres, e o precário acesso aos locais mais distantes levava a maioria dos católicos a criar práticas e rituais religiosos que escapavam ao controle da Instituição. Por isso, as Constituições se dedicaram longamente a estabelecer os parâmetros que deveriam ser seguidos por todas as dioceses e paróquias e por seus seguidores. Da missa aos cemitérios, quase nada escapou ao olhar atento do episcopado que queria garantir até mesmo os detalhes dos rituais e das atividades do clero e dos católicos.

Mas tudo o que foi estabelecido acima teria pouca efetividade se não houvesse um clero comprometido e capaz de executar as orientações do episcopado. Por isso o título que trata da Disciplina do Clero foi dividido em dezenove capítulos e quatrocentos e noventa itens. E se, na Pastoral Coletiva, os bispos fizeram ressalvas às ordens e às congregações religiosas, nas Constituições Diocesanas se reportariam ao clero especialmente no que dizia respeito à sua formação e à disciplina. Abordando desde o Romano Pontífice até os institutos de votos simples, mostravam sua angústia em relação ao preparo dos seus auxiliares diretos. Por esta razão esmiuçaram todos os aspectos da corporação clerical, detalharam as práticas e as atividades que abrangiam desde a formação intelectual e espiritual até a honestidade na vida de cada sacerdote. Assim, o cabido da Catedral, os vigários capitulares, os cônegos, os consultores diocesanos, os examinadores, os vigários forâneos, os párocos e os coadjutores, os seminários, o clero, a vida sacerdotal, os clérigos estrangeiros, as ordens religiosas, as religiosas de votos solenes e os institutos de votos simples, tudo foi minuciosamente detalhado. Nenhum membro da hierarquia ou de vida consagrada poderia alegar 
desconhecimento das suas funções, de seu papel e de como deveria preparar-se e comportar-se para continuar pertencendo a esta categoria de membros da Igreja.

Mas, se o clero gerava angústia nos pastores das dioceses, menor não poderia ser a preocupação com os católicos. Por isso dedicaram um título específico denominado Costumes do Povo, dividindo-o em quatorze capítulos e duzentos e dezesseis itens. Para os bispos, os males que assolavam a sociedade somente seriam banidos se o clero em geral conseguisse melhorar os próprios hábitos e os costumes do povo. Lá estavam as almas que deveriam ser salvas para Cristo. Por isso, o documento penetra em todos os espaços de sociabilidade e nos ambientes particulares, nos familiares, nos escolares, nos espaços públicos como nas classes operárias, nas associações católicas, nas confrarias e nas irmandades, nas ordens terceiras, nas missões e nas dioceses.

Finalmente o título VI fora organizado em apenas um capítulo e um item. Assim se manifestam os bispos: Item 1677

Depois de ter estudado e discutido devidamente as Constituições acima registradas, as achamos em tudo conformes com as leis, tradições e louváveis costumes de Nossa Santa Egreja, cujo exame e juízo, de coração e com filial docilidade, sujeitamos tudo quanto ahi ficou decretado e sanccionado. E para que as dictas Constituições tenham força de lei obrigatória, Nós as promulgamos e temos por promulgadas, cada um para sua dioceses, com a publicação delas neste volume, e mandamos que se observem e guardem inteiramente pelos nossos Cabidos metropolitanos e diocesanos, pelo Rvd. Clero secular e regular, pelas Communidades religiosas, pelos seminários diocesanos de qualquer natureza e por todos os que estão sujeitos à Nossa Jurisdição. (IGREJA CATÓLICA. Bispos, 1915)

Ao texto das Constituições eram acrescidos 84 apêndices com orientações detalhadas sobre procedimentos que, embora nem sempre fossem de caráter doutrinário, eram recomendações que visavam unificar procedimentos, práticas litúrgicas, cerimoniais, atos de consagração entre tantos outros que não cabe citá-los neste texto.

\section{Considerações Finais}

Para finalizar, cabe reiterar que o conjunto dessa obra considerada "portentosa" pelas lideranças e pela catolicidade, constituiu-se no guia e na segurança das ações dos 
bispos, dos párocos, dos sacerdotes e dos fieis de todo o Brasil. Mesmo para os católicos que militassem nas mais distantes paróquias ou frequentassem minúsculas capelas nos longínquos rincões, para os que continuassem a ter escassos contatos com seus bispos e recebessem esparsas visitas de sacerdotes ou vivessem sob a mais rudimentar assistência religiosa, as Constituições Diocesanas estabeleceram os rumos que deveriam imprimir ao seu trabalho e davam certa garantia para suas práticas ritualísticas e para sua consciência. Eram diretrizes que incluíam desde os comportamentos sociais e as manifestações públicas da fé, até as práticas religiosas mais íntimas e privativas de cada crente.

Mesmo prontas em 1915, dois anos mais tarde, com a publicação do novo Código de Direito Canônico em 1917, sofreram algumas adequações, sem prejuízo de seu conteúdo original. Teoricamente, eram um documento completo e representavam o esforço para se adequar a Igreja Católica Romana do Brasil à legislação e às orientações do Concílio Plenário Latino Americano e da Sé Romana. Todavia, ao que parece, na prática nem tudo correra conforme o desejo do episcopado. Em 1945, Padre Manoel Barbosa em sua obra A IGREJA NO BRASIL - notas para sua historia, referindo-se às Constituições Diocesanas, destaca: "Quantos ensinamentos poderiam ter sido transmitidos, por intermédio desse monumento da legislação eclesiástica". (BARBOSA, 1945. P.159). Quando o autor diz "poderiam" é porque ele mesmo reconhece que, apesar do mando dos bispos para que elas fossem lidas nas paróquias e seminários, eram quase desconhecidas dos católicos e de boa parte do clero.

E, ainda que não se tenha condições de avaliar o quanto estas Constituições foram estudadas e assumidas pelo clero e pela catolicidade, bem como o quanto efetivamente modificaram os costumes do povo católico e das autoridades, não será exagero afirmar-se que, na conjuntura de uma instituição autônoma e livre das amarras da estrutura administrativa do Estado, após 25 anos de atividades, nascia uma Instituição que estabelecera os parâmetros para e por onde deveriam caminhar seus seguidores.

Ao que tudo indica, os próprios bispos não tinham condições de avaliar o quanto as Constituições foram observadas e obedecidas, e, por esta razão, preocupados com a Igreja que estava em construção no início do século XX, com a vida cotidiana dos católicos, com o comportamento e com os procedimentos do clero e querendo organizá- 
la a partir de novos parâmetros, inseri-la nas determinações da Sé Romana, nas decisões e determinações do Concílio de Trento e do Concílio Plenário Latino reiterava a obrigatoriedade de sua leitura sempre que a ocasião o permitisse, mas, sobretudo nas missas e nos seminários de formação do clero. Consideravam-nas um instrumento de ensino da religião sem distinção de condição social e intelectual. Cabe então ressaltar que elas além de conter o discurso fundador, eram a expressão da nova Igreja que surgia a partir do século XX.

\section{Referenciais}

BARBOSA, Manoel (padre). A Igreja no Brasil - Notas para a sua história. Rio de Janeiro: Editora e Obras Graficas A NOITE, 1945.

BRANDÃO, Helena N. Nagamine. Introdução à Análise do Discurso. Campinas, SP: editora da Unicamp, 1998.

BOURDIEU, P. A Economia das trocas linguísticas. São Paulo: EDUSP, 1996.

IGREJA CATÓlICA. Bispos. PASTORAL COLLECTIVA dos Senhores Arcebispos e Bispos das Províncias Ecclesiasticas de S. Sebastião do Rio de Janeiro, Mariana, S. Paulo, Cuyabá e Porto Alegre comunicando ao Clero e Fieis o resultado da Conferencias Episcopaes realizadas na cidade de Nova Friburgo de 12 a 17 de janeiro de 1915. Rio de Janeiro: Typ. Martins de Araujo \& C., 1915.

Acta et Decreta Cocilii Plenarii Americae Latinae. Romae: Typis Vaticanis, MCMII.

MAINGUENEAU, D. Gênese dos discursos. São Paulo: Parábola Editorial, 2008.

ORLANDI, Eni Pulcinelli (Org.). Discurso Fundador. Campinas, SP: Pontes 1993. 2005.

Recebido: 04/03/2016

Received: 03/04/2016

Aprovado: 30/05/2016

Approved: 05/30/2016 